\title{
PEMBERDAYAAN UMKM DI KECAMATAN RA'AS MELALUI PENDAMPINGAN STANDARISASI PRODUK DAN KEMASAN
}

\author{
Anik Anekawati ${ }^{1)}$, Roos Yuliastina ${ }^{2)}$, Isdiantoni ${ }^{3)}$, Syahril ${ }^{4)}$, Edy Purwanto ${ }^{5)}$, Mohammad \\ Hidayaturrahman $^{6}$ \\ 1,)FKIP, Universitas Wiraraja, ${ }^{2,6)}$ Fakultas Ilmu Sosial dan Ilmu Politik, Universitas Wiraraja, \\ ${ }^{3)}$ Fakultas Pertanian, Universitas Wiraraja, ${ }^{4,5)}$ Fakultas Ekonomi Bisnis, Universitas Wiraraja, \\ E-mail : anik@wiraraja.ac.id
}

\begin{abstract}
Abstrak
Kegiatan Pengabdian kepada Masyarakat $(\mathrm{PkM})$ ini berupaya meningkatkan kemampuan pelaku UMKM dalam mengelola produk yang dihasilkan menjadi produk unggulan Kecamatan Ra'as. Kegiatan ini melakukan pendampingan standarisasi mutu produk, inovasi produk, perbaikan pengemasan, branding dan pemasaran, serta pembentukan kelompok usaha bersama untuk meningkatkan kemampuan daya tawar pasar. Metode pelaksanaannya terdiri dari 4 tahapan yakni (1). Survey UMKM di Kecamatan Ra'as di 9 desa; (2) Focus Group Discussion (FGD); (3) Pelatihan dan pendampingan UMKM; (4). Monitoring pasca pendampingan. Hasil survei menunjukkan bahwa terdapat 113 UMKM yang tersebar di 9 desa Kecamatan Ra'as. Jumlah tersebut terdiri dari 78 UMKM yang bergerak di bidang makanan atau minuman dan 35 di bidang kerajinan. Hasil kegiatan FGD adalah mengklarifikasi hasil survei UMKM dan menentukan produk unggulan. Hasil pelatihan dan pendampingan UMKM antara lain standarisasi produk ikan kering, standarisasi kemasan, pembuatan merek dan logo, pelatihan diversifikasi produk baru dari bahan jagung lokal, pelatihan pemasaran online, dan sosialisasi desain awal marketplace.
\end{abstract}

Kata kunci : Standarisasi Produk, Merk, Logo, Diversifikasi Produk

\section{Pendahuluan}

Sumenep dikenal sebagai salah satu daerah yang memiliki potensi hasil laut dan tani yang melimpah (Pemda Sumenep, 2018). Hasil laut yang dimaksud adalah berbagai jenis ikan dan rumput laut. Sedangkan hasil tani terdiri dari padi dan jagung. Salah satu Kecamatan di Kabupaten Sumenep yang memiliki keunggulan pada hasil laut dan hasil tani adalah Kecamatan Ra'as.

Berdasarkan data yang diperoleh dari Badan Pusat Statistik, komoditas tanaman padi/palawija, Kecamatan Ra'as paling banyak menghasilkan jagung dengan tingkat produksi sebanyak 20.379 ton, sayursayuran paling banyak memproduksi cabe rawit sebesar 78,3 ton dan tingkat produksi paling unggul di sektor buah-buahan yaitu mangga sebanyak 1860 ton (BPS, 2019). Sebagian hasil laut dan hasil tani tersebut, sudah dimanfaatkan oleh masyarakat Usaha Mikro Kecil dan Menengah (UMKM).
Menurut Permana (2017) UMKM memegang peranan penting dalam pertumbuhan ekonomi khususnya di Indonesia. Ihza (2020) menambahkan bahwa UMKM di Indonesia jumlahnya sangat banyak. Mulai dari produk makanan, minuman, kerajinan, pakaian, dan lain sebagainya. Sehingga dibutuhkan inovasi produk untuk membedakan dari produk satu dengan yang lainnya. Selain itu diperlukan juga pengetahuan mengenai faktor-faktor yang mempengaruhi keberhasilan suatu usaha (Nandita, Sarma, dan Najib, 2018).

Oleh sebab itu, keterampilan khusus yang harus dimiliki pelaku UMKM mempunyai peran strategis. Hal ini bertujuan untuk mempertahankan usahanya. Salah satu keterampilannya adalah keterampilan inovasi dan kreasi produk, sehingga mampu menghasilkan karya atau produk baru (Marlina dan Lina, 2020). Ihza (2020) menambahkan bahwa keterampilan dasar dalam berusaha juga sangat penting 
dimiliki oleh pelaku UMKM untuk tetap menjaga eksistensi dalam menjalankan usaha.

Salah satunya adalah menjaga standarisasi produk (Khoryanton, 2015) memberi kemasan (packaging) yang baik serta menciptakan brandimage sehingga bisa menarik perhatian masyarakat dan mendapatkan pasar atau pelanggan baru (Marlina dan Lina, 2020). Selain itu, dibutuhkan pula suatu standarisasi mutu yang baik pada suatu produk (Khoryanton, 2015). Hal ini bertujuan untuk menyiapkan strategi pemasaran yang lebih luas bisa bersaing di pasar nasional atau internasional (Marlina, 2020).

Namun, Faktanya berbeda seperti yang ada di lapangan. Pelaku UMKM di Kecamatan Ra'as hanya menjalankan usaha untuk menghidupi kebutuhan sehari-hari. Sehingga produk yang dihasilkan dalam UMKM tidak mengikuti standarisasi mutu yang sesuai. Secara garis besar, produkproduk yang dihasilkan oleh UMKM di Kecamatan Ra'as hanya berupa produk panganan masyarakat setempat yang tidak terlalu berorientasi pasar.

Berdasarkan dari uraian tersebut, maka Program Pemberdayaan UMKM di Kecamatan Ra'as difokuskan pada upaya peningkatan kemampuan pelaku UMKM dalam mengelola produk yang dihasilkannya, menjadi produk unggulan Kecamatan Ra'as. Program ini dilakukan melalui pendampingan standarisasi mutu produk, inovasi produk, perbaikan pengemasan, branding dan pemasaran, serta pembentukan kelompok usaha bersama untuk meningkatkan kemampuan daya tawar pasar.

Secara garis besar permasalahan yang dihadapi oleh pelaku UMKM di Kecamatan Ra'as, yaitu: (a). Tidak ada data real UMKM terkait jumlah dan jenis UMKM di Kecamatan Ra'as, sehingga sulit dipetakan; (b). Permasalahan bahan baku; (c). Standarisasi produk mulai dari pengolahan, kemasan dan logo; (d). Permasalahan pemasaran.

\section{Metode}

Pelaksanaan kegiatan program pemberdayaan UMKM Kecamatan Ra'as dibagi menjadi 4 kegiatan utama, yaitu:

a. Survey UMKM di Kecamatan Ra'as terdiri dari 9 desa.

b. Focus Group Discussion (FGD) melibatkan perwakilan UMKM masingmasing desa dan aparat setempat

c. Pelatihan dan pendampingan UMKM terdiri dari kegiatan: pelatihan standarisasi produk ikan kering, pelatihan kemasan, merek dan logo, pelatihan diversifikasi produk baru dari bahan jagung lokal, pelatihan pemasaran online, dan sosialisasi desain awal marketplace.

d. Monitoring pelaksanaan hasil pendampingan oleh UMKM.

\section{Hasil dan Pembahasan}

Hasil kegiatan $\mathrm{PkM}$ akan diuraikan sebagai berikut:

\section{A. Hasil kegiatan survei UMKM}

Kecamatan Ra'as memiliki 9 desa dengan jumlah keseluruhan 113 UMKM. Berikut merupakan rincian UMKM di masing-masing desa di Kecamatan Ra'as.

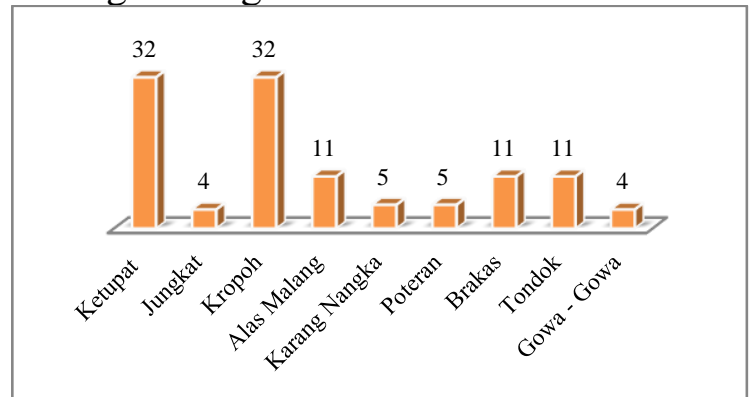

Gambar 1. Jumlah UMKM di Kecamatan Ra'as

Gambar di atas menunjukkan bahwa Desa Ketupat dan Desa Kropoh memiliki jumlah UMKM paling banyak yakni 32 . Sedangkan paling sedikit adalah Desa Jungkat dan Desa Gowa-Gowa. 
Berikut merupakan uraian jumlah dan jenis UMKM yang ada di Kecamatan Ra'as.

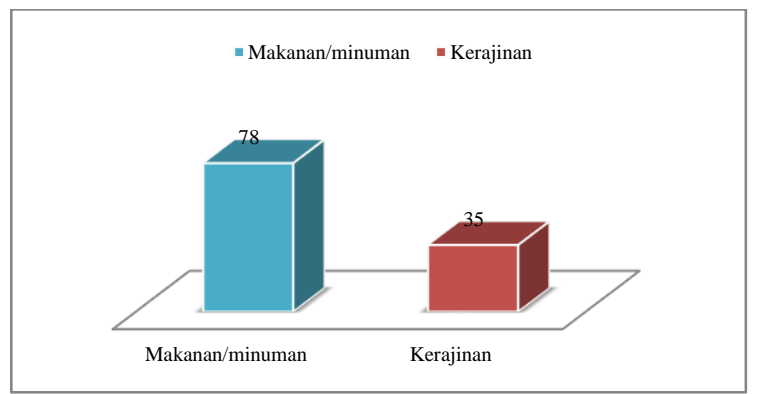

Gambar 2. Jumlah dan Jenis UMKM di Kecamatan Ra'as

Gambar 2 menunjukkan bahwa UMKM yang bergerak di bidang makanan dan minuman sebanyak 78 sedangkan di bidang kerajinan sebanyak 35 .

Berikut akan diurai jumlah dan jenis UMKM pada setiap Desa di Kecamatan Ra'as.

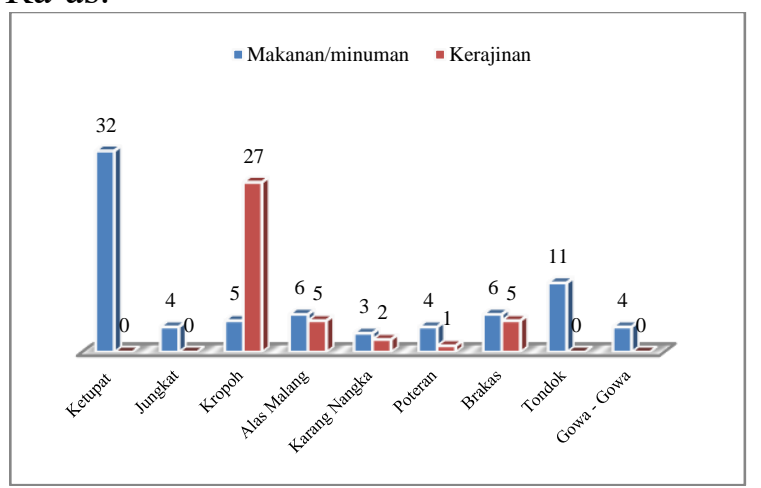

Gambar 3. Jumlah dan Jenis UMKM di Setiap Desa

Berdasarkan gambar di atas, mayoritas desa di Kecamatan Ra'as memiliki jenis UMKM makanan atau minuman.

Berikut merupakan gambaran permasalahan yang dihadapi UMKM Kecamatan Ra'as berdasarkan hasil survei.

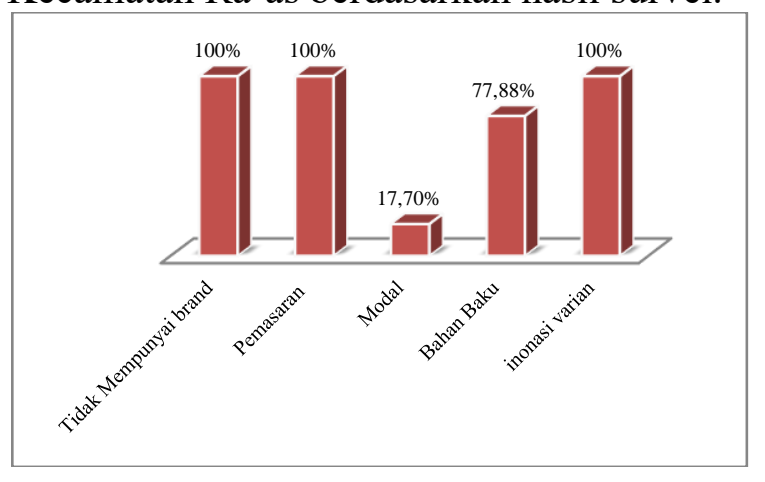

\section{Gambar 4. Permasalahan UMKM}

Gambar 4 menunjukkan bahwa semua UMKM di Kecamatan Ra'as mempunyai permasalahan terkait branding, pemasaran dan inovasi varian. Sebagian besar UKMM juga mempunyai permasalahan dengan modal dan bahan baku, dimana masih tergantung dengan ketersediaan sesuai dengan sumber daya alam yang bersifat musiman.

Berikut akan ditampilkan bahan baku yang digunakan sebagai produk olahan UMKM Jenis Makanan di Kecamatan Ra'as.

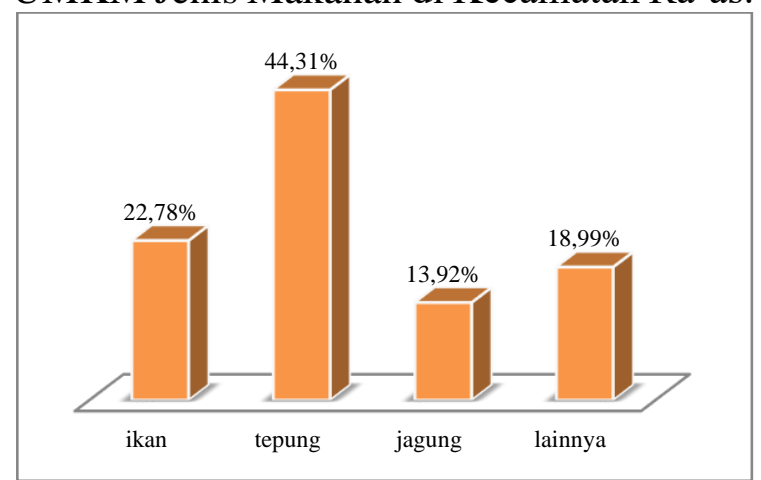

Gambar 5. Bahan Baku UMKM Jenis Makanan

Gambar di atas menunjukkan UMKM jenis makanan berbahan baku tepung memiliki persentase sebesar 44, 31\%. Kemudian disusul bahan baku ikan $(22,78 \%)$, lainnya $(18,99 \%)$, dan jagung $(13,92 \%)$.

\section{B. Hasil Kegiatan Focus Group Discussion (FGD)} adalah:

Hasil FGD sebagaimana tujuannya

a. Hasil survei UMKM sebagaimana yang dipaparkan sebelumnya telah diklarifikasi kebenarannya oleh peserta UMKM yang hadir di acara FGD.

b. Hasil pemetakan berdasarkan survei telah klarifikasi dan dipahami oleh peserta UMKM yang hadir di acara FGD.

c. Didapatkan pemetakan permasalahan dan solusinya

Solusi yang ditawarkan kepada UMKM diprioritaskan berdasarkan pada 
permasalahan yang dialami oleh semua UMKM, yaitu masalah branding, pemasaran, dan inovasi varian. Upaya menyelesaikan permasalahan UMKM dipetakan dan dicarikan solusi adalah sebagaimana tertera pada tabel berikut:

Tabel 1. Permasalah dan Solusi UMKM

\begin{tabular}{|l|l|l|}
\hline Permasalahan & \multicolumn{1}{|c|}{$\begin{array}{c}\text { Sumber } \\
\text { Informasi }\end{array}$} & $\begin{array}{l}\text { Solusi yang } \\
\text { Ditawarkan }\end{array}$ \\
\hline Branding & $\begin{array}{l}\text { Survey } \\
\text { UMKM }\end{array}$ & $\begin{array}{l}\text { Pelatihan dan } \\
\text { pendampingan } \\
\text { kemasan produk, } \\
\text { merek, dan logo }\end{array}$ \\
\hline Pemasaran & $\begin{array}{l}\text { Survey } \\
\text { UMKM }\end{array}$ & $\begin{array}{l}\text { Pelatihan dan } \\
\text { pendampingan } \\
\text { pemasaran } \\
\text { (Online) }\end{array}$ \\
\hline Inovasi varian & $\begin{array}{l}\text { Survey } \\
\text { UMKM }\end{array}$ & $\begin{array}{l}\text { Pelatihan dan } \\
\text { pendampingan } \\
\text { diversivikasi } \\
\text { produk berbahan } \\
\text { jagung (produk } \\
\text { mie berbahan } \\
\text { dasar jagung dan } \\
\text { nasi jagung instan) }\end{array}$ \\
\hline Bahan Baku & $\begin{array}{l}\text { Survey } \\
\text { UMKM }\end{array}$ & $\begin{array}{l}\text { Pelatihan dan } \\
\text { pendampingan } \\
\text { standarisasi } \\
\text { produk }\end{array}$ \\
\hline $\begin{array}{l}\text { Kelayakan } \\
\text { produk }\end{array}$ & $\begin{array}{l}\text { Hasil } \\
\text { observasi tival } \\
\text { Universitas } \\
\text { Wiraraja }\end{array}$ \\
\hline
\end{tabular}

Sumber: Data olahan Tim Pengabdi (2020)

d. Produk unggulan yang akan didampingi dalam pelatihan

Hasil FGD ini menyepakati bahwa akan dilakukan pendampingan produk UMKM dengan bahan dasar dari hasil laut, hasil pertanian, dan 1 produk dengan bahan dasar dari luar keduanya. Produk UMKM dari bahan dasar hasil laut adalah petis, ikan kering, dan abon. Hal ini dikarenakan produk tersebut yang sudah sering diproduksi. Produk UMKM dari bahan dasar hasil pertanian adalah jagung. Alasannya karena jagung di Kecamatan Ra'as banyak diproduksi dan sifatnya spesifik berbeda dengan jagung di tempat lain. Produk UMKM dari bahan dasar lainnya adalah dodol, karena produk ini sudah lama diproduksi oleh masyarakat setempat.

Hasil FGD berkembang di luar yang ditargetkan, yaitu perlu adanya diversitifikasi produk olahan dari jagung sebagai solusi atas permasalahan keterbatasan bahan pada musim tertentu. Pada akhirnya, ditambahkan kegiatan pengenalan produk hasil diversifikasi dari jagung, yaitu mie jagung dan beras instan jagung.

\section{Hasil Kegiatan Pelatihan dan Pendampingan}

Pelaksanaan kegiatan pelatihan dan pendampingan yang dilaksanakan pada hari Sabtu tanggal 14 sampai 15 Desember 2019 bertempat di Kantor Desa Alasmalang. Pelaksanaan kegiatan pelatihan dan pendampingan dihadiri oleh Camat Ra'as, Perwakilan COMDEV KEI, Tim Pelaksanaa kegiatan pelatihan dan pendampingan, Pelaku UMKM Kecamatan Ra'as serta Aparat desa Alasmalang.

Hasil dari pelatihan akan diuraikan satu per satu pada paparan berikut:

\section{a. Standarisasi Produk Hasil Pendampingan}

Untuk mendapatkan produk pangan yang sesuai dengan keinginan pasar, maka pelatihan UMKM di kecamatan Ra'as, difokuskan pada 3 (tiga) hal yaitu: (1) Hygenitas; (2) kualitas produk dan (3) kemasan. Pelatihan UMKM di Kecamatan Ra'as diarahkan kepada cara produksi pangan yang baik untuk industri rumah tangga dengan berpedoman pada Peraturan Kepala Badan Pengawas Obat dan Makanan Republik Indonesia Nomor Hk.03.1.23.04.12.2206 Tahun 2012 dan Standar Nasional Indonesia (SNI) dari masing-masing produk pangan yang dihasilkan.

\section{b. Standarisasi Kemasan Hasil Pendampingan}

Pengemasan merupakan suatu cara pengamanan terhadap produk makanan agar makanan baik yang belum diolah maupun yang telah diolah, dapat sampai ke tangan konsumen dengan baik, secara kuantitas maupun kualitas. 


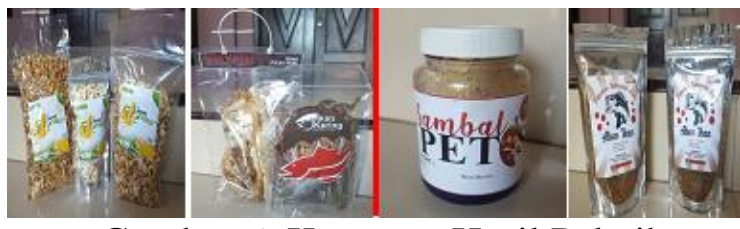

Gambar 6. Kemasan Hasil Pelatihan

Persyaratan kemasan pada pelatihan ini adalah: harus cocok dengan bahan yang dikemas, menjamin kebersihan makan yang akan dikemas, dan kemudahan dan keamanan makanan saat dikeluarkan dari kemasan. Gambar 6 adalah kemasan hasil pendampingan.

\section{c. Standarisasi Merek dan Logo Hasil Pendampingan}

Salah satu kekuatan brand adalah membangun loyalitas pelanggan. Salah satu kegiatan membangun brand yang sangat penting adalah mendesain identitas visual berupa merek dan logo, karena merek dan logo merupakan pintu masuk yang mencerminkan sebuah brand. Oleh sebab itu, merek dan logo harus dapat menampilkan pribadi dan jiwa entitas yang diwakilinya. Gambar 7 berikut adalah merek dan logo hasil pendampingan.

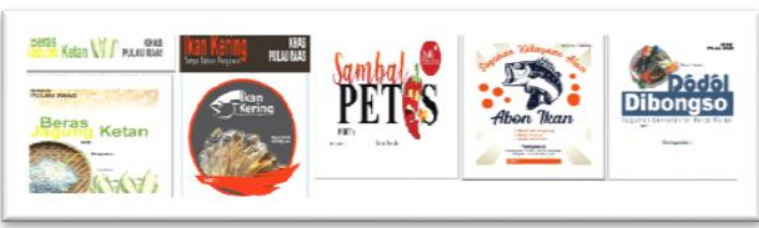

Gambar 7. Merk dan Logo Hasil Pendampingan

\section{d. Pengurusan dan Pendaftaran Merek dan Logo UMKM khas Ra'as}

Adapun proses pengurusan merek dan logo 5 produk UMKM khas Ra'as dilakukan melalui sentra HKI milik Universitas Wiraraja yang berada di bawah naungan Lembaga Penelitian dan Pengabdian Universitas Wiraraja.

Alur pertama, tim tetap akan melakukan pendampinan kepada kelompok UMKM Ra'as yang telah terbentuk melalui kegiatan pengabdian. Adapun pendampingan yang dimaksud adalah pendampingan dalam pemrosesan pengurusan berkas pendaftaran dan persyaratan yang dibutuhkan. Pendampingan pengurusan HKI merek dan logo 5 produk khas Ra'as bertujuan untuk mempermudah dalam merealisasikan merek dan logo khas produk Ra'as yang terstandarisasi sehingga menambah nilai jual produk melalui marketplace "Wiraraja store online."

Pengurusan HKI merek dan logo 5 produk khas Ra'as diarahkan untuk menggunakan jalur pendaftaran atas nama kelompok UMKM. Adapun tujuannya selain secara biaya lebih ekonomis nantinya sertifikat HKI produk - produk tersebut akan dimiliki oleh kelompok UMKM.

\section{e. Desain Awal Market place}

Gambar berikut adalah grand desain untuk pemasaran produk UMKM seluruh binaan Universitas Wiraraja yang memanfaatkan pemasaran offline dan online (marketplace).

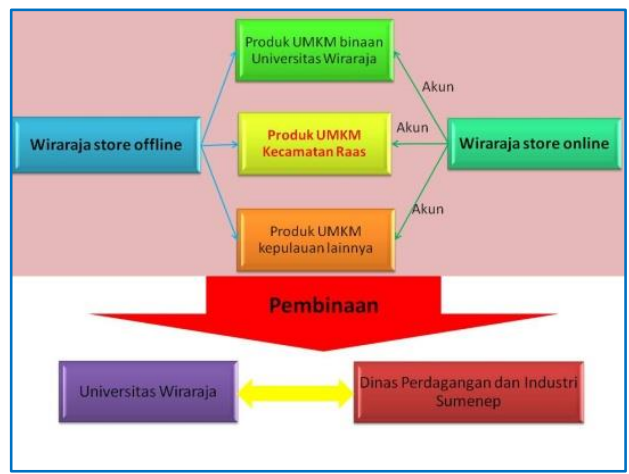

Gambar 8. Grand Desain Pemasaran

Wiraraja store online akan dibuat beberapa pemegang akun, terutama paguyupan UMKM yang berada di kepulauan. Pelayanan pembelian bisa dilakukan oleh masing-masing akun atau dilakukan master akun dengan asumsi barang ready di Wiraraja store offline. Pada desain marketplace akan muncul lokasi dan barang yang tersedia (dalam pengembangan) yang akan dipilih sendiri oleh konsumen lokasi pengiriman barang.

Berikut ini adalah desain awal Wiraraja store online (market place). Halaman depan tampak pada Gambar 9, dengan fitur Home, Produk, kontak Kami, Info Pembayaran, Pembayaran, Admin. Desain awal ini belum mempunyai web dan 
hosting, maka masih menggunakan sub domain milik LPPM Universitas Wiraraja untuk sementara waktu.

Sedangkan desain bagian
administrasi tampak pada Gambar 10, dengan fitur home, master data, laporan, pesanan, pembayaran, kontak, dan logout. Fitur master berisikan data user, data produk, data kategori produk, kota dan ongkos kirim. Tujuan dari fitur ini adalah input user, produk, kategori dan penentuan ongkir oleh administrasi. Fitur laporan berisikan laporan pengeluaran, input pengeluaran, laporan laba-rugi, laporan penjualan, dan input penjualan yang dioperasikan oleh adminsitrasi. Fitur pesanan berisikan status pemesanan apakah sudah terbayar, terkirim, selesai atau dibatalkan. Fitur pembayaran digunakan untuk untuk mengetahui status pembayaran dan jumlahnya. Fitur kontak digunakan untuk menyimpan kontak yang dianggap penting.

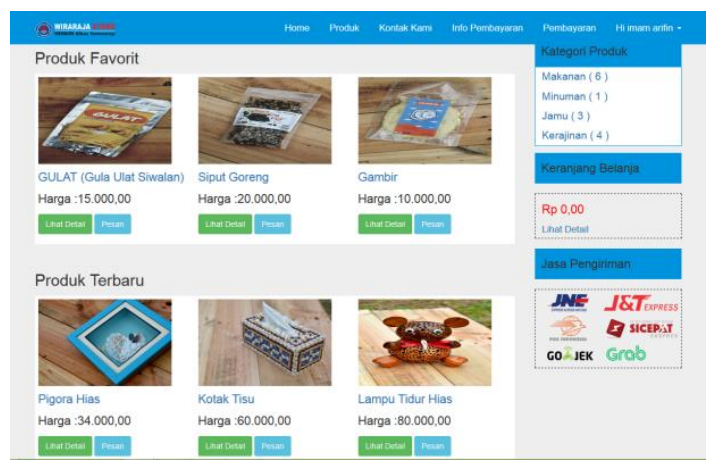

Gambar 9. Gambar Tampak Depan beserta Fitur Desain Awal Marketplace.

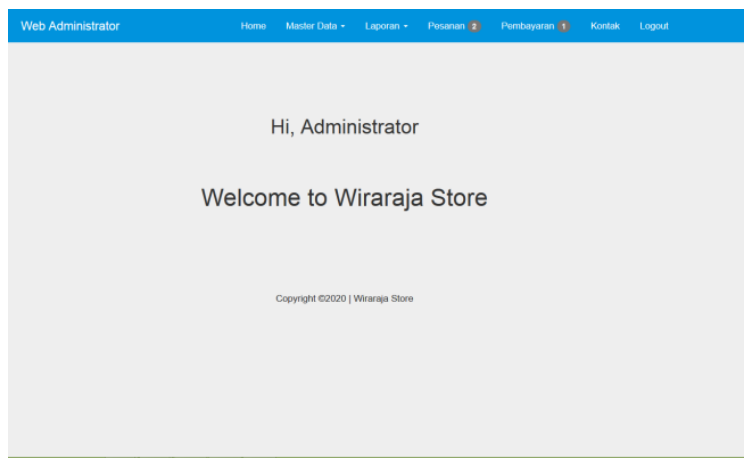

Gambar 10. Gambar Tampak Depan Bagian Admin beserta Fitur Desain Awal Marketplace

\section{f. Terbentuknya Paguyuban UMKM Kecamatan Ra'as}

Kegiatan pelatihan dan pendampingan UMKM Kecamatan Ra'as menghasilkan kelompok UMKM Kecamatan Ra'as. Pembentukan kelompok ini bertujuan untuk mempermudah komunikasi dengan pelaku UMKM di Kecamatan Ra'as. Susunan pengurus kelompok UMKM sebagaimana Tabel 2.

Tabel 2. Susunan Pengurus Kelompok UMKM

\begin{tabular}{llll}
\hline \multicolumn{1}{c}{ Jabatan } & \multicolumn{1}{c}{ Nama } & \multicolumn{2}{c}{ Desa } \\
\hline Ketua & $\begin{array}{l}\text { Ika Rahayu } \\
\text { Sintiya Dewi } \\
\text { Wakil }\end{array}$ & Alasmalang & \\
Ketua & & Brakyah & \\
Bendahara & Nuris & Ketupat & \\
Sekretaris & Yundari & Ketupat & \\
Anggota & Pelaku & $9 \quad$ Desa & di \\
& UMKM Kec. & Kec.Ra'as & \\
& Ra'as & & \\
\hline
\end{tabular}

\section{Monitoring Pelaksanaan Hasil Pendampingan}

Dalam kegiatan pengabdian ini, tim program pemberdayaan UMKM Kecamatan Ra'as Universitas Wiraraja berkomitmen untuk terus mendampingi baik sebagai rekan maupun sebagai konselor bagi mitra kelompok UMKM kecamatan Ra'as jika membutuhkan informasi dan bantuan lainnya terkait pengembangan produk produ khas Ra'as. Khusunya pasca pelatihan program pemberdayaan UMKM ini tim program pemberdayaan Unija akan terus mengawal dan memfasilitasi proses pendaftaran 5 merek dan logo milik UMKM Kecamatan Ra'as sampai selesai.

Kegiatan monitoring telah dilakukan setidaknya dua kali pasca kegiatan pendampingan. Harapannya program pemberdayaan ini dapat terus kontinyu diterapkan sehingga lahir program - 
program pemberdayaan berikutnya di tahun yang akan datang.

\section{Simpulan}

Pemberdayaan UMKM ini dilakukan dengan cara pelatihan dan sosialisasi standarisasi mutu produk, inovasi produk, perbaikan pengemasan, branding dan pemasaran, serta pembentukan kelompok usaha bersama untuk meningkatkan kemampuan daya tawar pasar.

\section{Ucapan Terima Kasih}

Ucapan terima kasih disampaikan kepada Kangean Energy Indonesia (KEI) atas hibah dengan nomor kontrak (.....).

\section{Daftar Pustaka}

Badan Pusat Statistik, 2019. Sumenep dalam Angka 2019. Sumenep

Ihza, 2020. Dampak Covid-19 Terhadap Usaha Mikro Kecil Dan Menengah (UMKM) Studi Kasus UMKM Ikhwa Comp Desa Watesprojo, Kemlagi, Mojokerto. Jurnal Inovasi Penelitian. Vol.1 No.7. https://stp-mataram.ejournal.id/JIP/article/view/268

Khoryanton, 2015. Standarisasi Produk Guna Meningkatkan Daya Saing Industri Kecil Menengah Komponen Kapal di Kabupaten Tegal. POLINES National Engineering. ISSN 2503-2771. http://digilib.mercubuana.ac.id/manager /t! @file_artikel_abstrak/Isi_Artikel_25 5672282619.pdf

Marlina, Lina. 2020. Peluang dan Tantangan UMKM Dalam Upaya Memperkuat Perekonomian Nasional Tahun 2020 Ditengah Pandemi Covid 19. Jurnal Ekonomi. Vol 22. No 2. https://ejournal.borobudur.ac.id/index.p $\mathrm{hp} / 1 /$ article/view/644

Nandita, Sarma, dan Najib. 2018. FaktorFaktor yang Memengaruhi Keberhasilan Usaha UMKM Pengolahan Buah dan Pengolahan Susu. Jurnal Manajemen dan Organisasi (JMO). Vol. 9. No. 1. https://media.neliti.com/media/publicati ons/274652-none-692ce3bd.pdf

Pemda Sumenep, 2018. Masterplan Smart City Kabupaten Sumenep. Sumenep. Pemda sumenep.

Permana, 2017. Strategi Peningkatan Usaha Mikro, Kecil, dan Menengah (UMKM) di Indonesia. Aspirasi .Vol. 8 No. 1. https://jurnal.dpr.go.id/index.php/aspira si/article/view/1257 